\title{
Application of Accounting and Reporting in a Cost-Oriented Quality Management in Wood- Processing Companies
}

\section{Primjena obračunavanja i izvještavanja u troškovno orijentiranom upravljanju kvalitetom u drvoprerađivačkim tvrtkama}

\author{
Review paper • Pregledni rad \\ Received-prispjelo: 29. 3. 2012. \\ Accepted-prihvaćeno: 15. 11. 2012. \\ UDK: $630 * 76$ \\ doi:10.5552/drind.2012.1215
}

\begin{abstract}
The company must constantly review its own computer system if it wants to maintain its competitiveness and ensure sustainable development in strong international environment. The company must monitor if the information system provides sufficient information, in terms of quantity and quality, for all its business activities. In order to improve its own position in the market, it must be adequately represented in the quality area, quality costs and the related quality indicators. We offer to companies an option to track quality costs and subsequently evaluate them.
\end{abstract}

Keywords: quality, quality control, quality costs, reporting

SAŽETAK・ Tvrtka mora stalno ispitivati svoj računalni sustav želi li održavati svoju konkurentnost i osiguravati održivi razvoj u jakome međunarodnom okruženju. Jednako tako, tvrtka mora pratiti pruža li njezin informacijski sustav dovoljnu količinu kvalitetnih informacija u svakom području njezine aktivnosti. Kako bi poboljšala svoju poziciju na tržištu, tvrtka mora biti kvalitetno prezentirana na području kvalitete, troškova kvalitete i pokazatelja kvalitete koji su u njima sadržani. Naš je prijedlog dati tvrtki primjerenu opciju praćenja troškova kvalitete i njihova sustavnog vrednovanja.

Ključne riječi: kvaliteta, kontroling u kvaliteti, troškovi kvalitete, izvještavanje

\section{INTRODUCTION \\ 1. UVOD}

Accountancy plays a vital role in the company. It is a source of information for a number of entities the entrepreneur comes into contact with by conducting its business. Owners, managers, investors, banks, insurance companies, unions and creditors are always intere- sted only in a particular area of results or in complex results of a company performance for a calendar period. Instead, they should be provided with high-quality information to be able to get a comprehensive picture of the company position.

All tasks, to be fulfilled by accountancy in a company, can only be carried out successfully if attention is paid not only to the financial accounting, but also to

\footnotetext{
Authors are professor and assistant at Faculty of Wood Science and Technology, Technical University, Zvolen, Slovak Republic.

${ }^{1}$ Autori su profesorica i asistentica Fakulteta znanosti o drvu i drvne tehnologije Tehničkog sveučilišta u Zvolenu, Zvolen, Slovačka Republika.
} 
cost accounting, which focuses on internal processes. For a successful company management in the market environment, such information is necessary for successful control. This paper confirms the need of high-quality economy, implying monitoring of quality costs as part of quality control. The current business environment requires speed, flexibility and quality. According to Šatanová et al. (2010) it is necessary to realize the fact that without good quality financial and economic management, a company can hardly stand the pressure of everyday competition.

\section{MATERIALS AND METHODS 2. MATERIJALI I METODE}

This paper presents the structure, status and role of accounting in Slovakia. Further, the application is presented of accounting and quality economy to quality control. Based on information obtained from the available literature, methodology and implementation of procedures for quality control have been proposed and applied to management of specific business processes. In the proposed solution, the selected models of quality costs have been applied, namely PAF model, where quality costs in defined cost types have been monitored. By using control procedure, it is recommended to compile quarterly, half annual and annual summary reports that are an important source for rational and effective company management. Results are presented in graphical form using MS Excel.

\section{RESULTS AND DISCUSSION} 3. REZULTATI I RASPRAVA

\subsection{Accounting in a company - its role and tasks}

\subsection{Obračunavanje u tvrtki - uloga i zadaća}

Each company in Slovakia is run in accordance with the Accounting Law No. 431/2002 and has an obligation to keep records of its activities related to the area of financial accounting. This area gives a picture of the company management, and its results are mainly used to provide information to external users in terms of profit and loss account, balance sheet and cash flow statement. For managing and further decision making about the direction of the company, such information does not provide sufficient explanatory power and is also available to potential competitors. For this reason, companies promoted the introduction of the so-called cost accounting, which deals with the economic fundamentals of the internal point of view. It presents a picture of the company management, its position and it is only for internal users who use the results obtained for the company management.

\subsection{Economy and quality control}

\subsection{Kontroling u ekonomici i kvaliteti}

Economy quality also monitors a special category of expenses called quality costs, which represent a financial outlay required for the activities associated with providing, maintaining and improving quality. It is an economic category used to evaluate the effectiveness and efficiency of processes, and the quality impact on the creation of profit, costs structure, output, income and sales. The quality costs provide information concerning the implementation of quality control system in the company, determine the optimal level of product quality or service and show the weaknesses of the company.

The quality costs are extremely imortant for management decision making and it is therefore necessary to introduce them in the company system of monitoring and evaluation. Figure 1 represents schematically the process of the system development.

Each company constantly tries to improve its business. For this reason companies try to implement and use new advanced knowledge in magement. Control is definitely one of them, and it has become an indispensable part of modern business management. According to Macík (1999) controlling is the "tool for integrating multiple information systems and management, including strategic and operational planning, accounting particularly financial and internal (operational costs), budgets, costing and other forms of evidence and reporting“" Quality cost reporting system is the basis of business of budget-type companies (Potkány, 2009). Information from corporate reporting can be used for establishing intradepartmental prices (Potkány, 2005). The concept of quality control is obtained by connecting the area of quality with controling, and however it is not widespread nor applied in Slovakia. Currently, the concept of quality control is process-orientated, not product-orientated, as in practice the concept of ISO standards and TQM promote just a procedural approach. One of the objectives of quality control is also to improve the overall quality of the company. In quality management, control involves several tasks: (a) it coordinates the business areas, (b) promotes quality management and (c) monitors and reviews performance measures by the provision of appropriate information. For this purpose several tools are used such as calculation of quality costs, quality indicators and quality of reporting.

\subsection{Quality control and reporting}

\subsection{Kontrola kvalitete i izvještavanje}

The actual application of the concept of quality control management to business processes can be divided into several stages.

In the first phase the state of the company is analyzed. Its quality objectives and processes are identified, and then classified. The goals themselves must be part of an overall strategic goal and future direction of the company. The idea is to maximize the measurable objectives and therefore quality should be a measurable value in the company, as the basic feature of quality control. The individual targets should be specified not only at the company level but also at the level of departments and workplaces. This process results in the specification of targets for the quality of the company (see Tab. 1).

After specifying the quality objectives, the main groups of quality costs were identified, taking into account the specific situation in the company. In our case, 


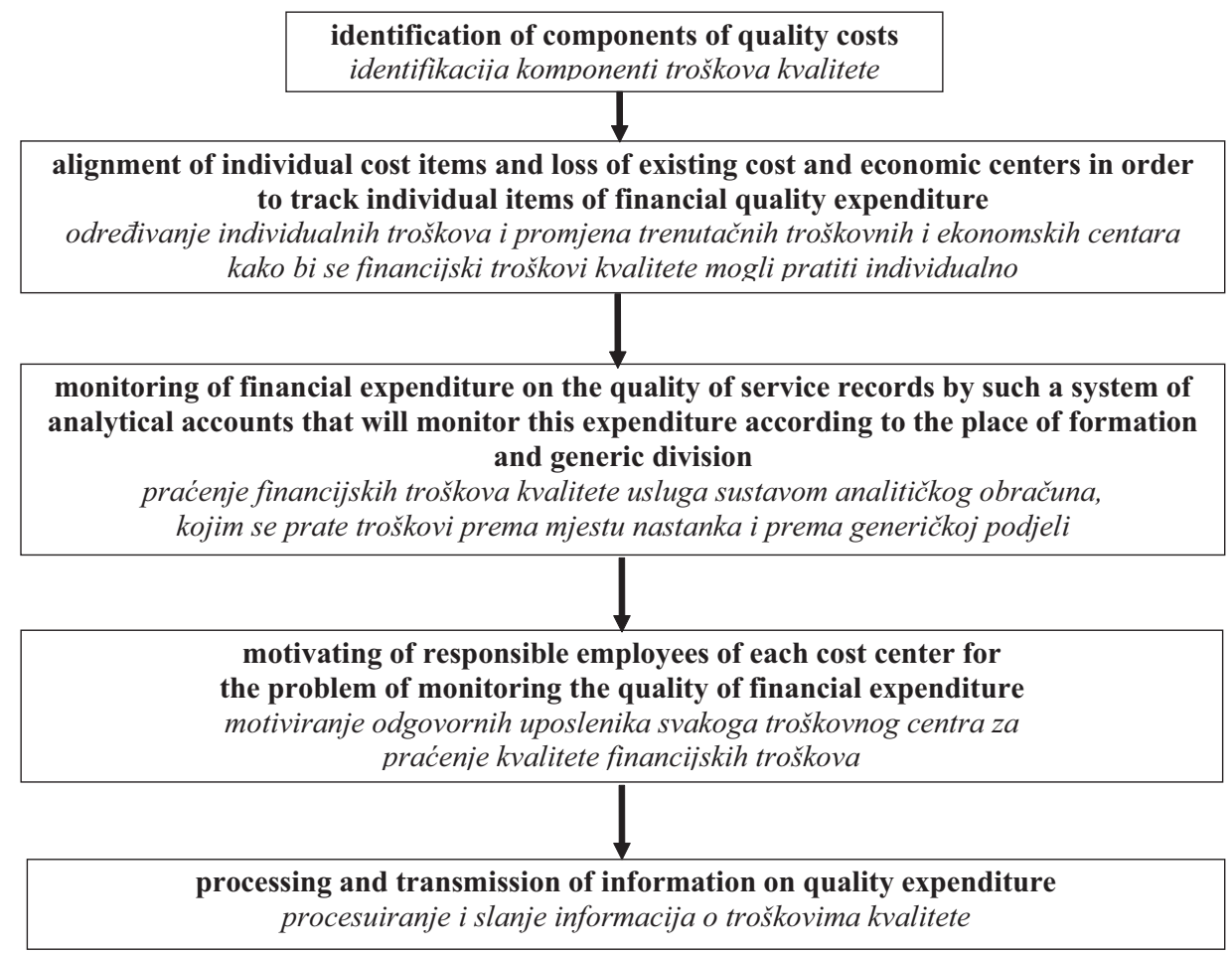

Figure 1 Building a system of monitoring and evaluation of costs (Šatanová et al., 2008)

Slika 1. Izgradnja sustava praćenja i vrednovanja troškova (Šatanová i sur., 2008)

the cost items in Table 2 will be subject to observation, and their distribution will be made according to the PAF model, which implies the division of quality costs to prevention costs, evaluation costs, and internal and external losses.
To see clearly the total quality costs, the use of MS Excel was recommended. With MS Excel the data would be processed in prepared workbooks. Every workbook also had to include sub-reports on the quality costs. These sub-reports would be checked monthly.

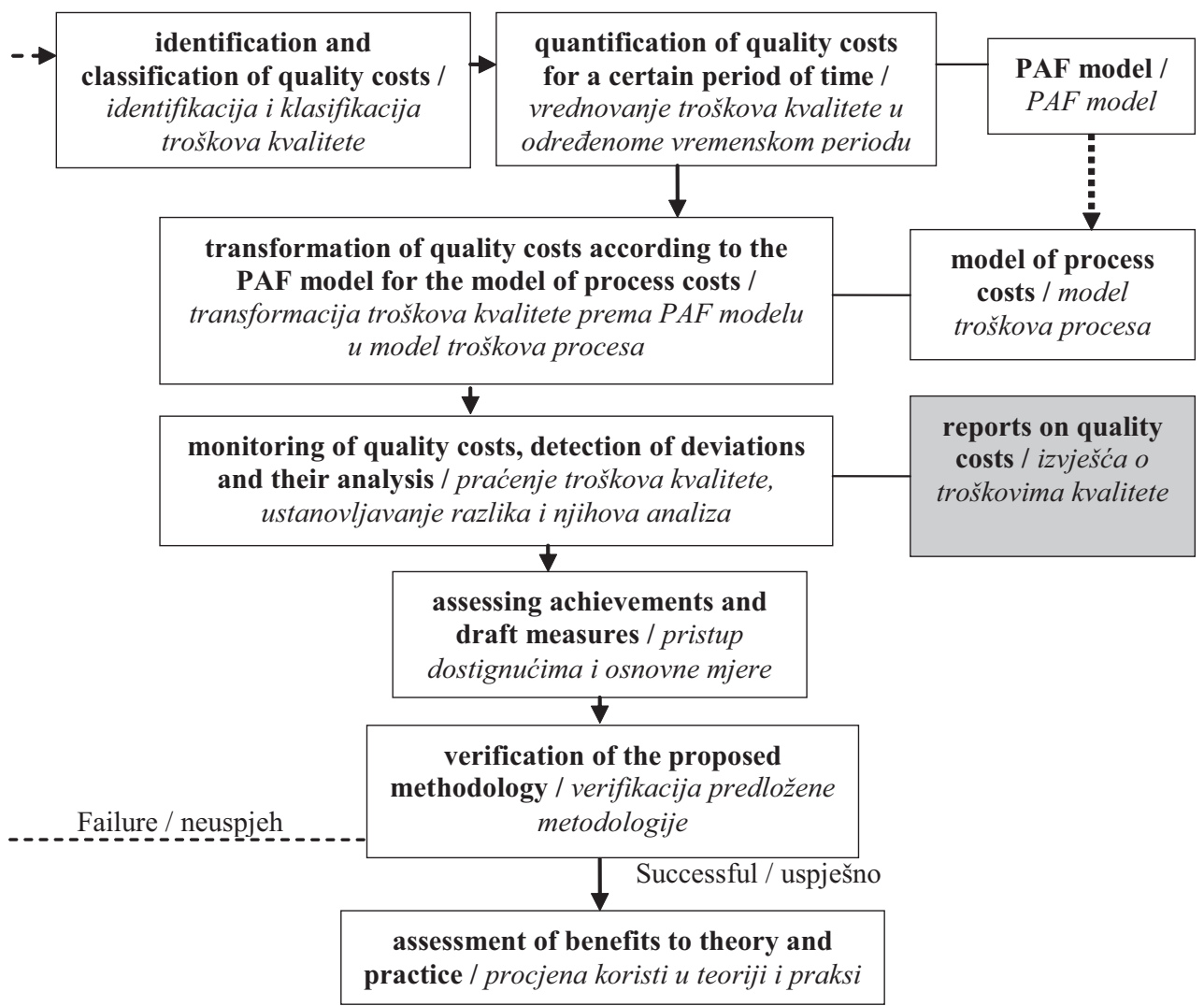

Figure 2 Methodology of the concept of quality control (Šatanová et al., 2008)

Slika 2. Metodologija i koncept kontrolinga kvalitete (Šatanová i sur., 2008) 
Table 1 Specification of quality targets (Šatanová et al., 2008)

Tablica 1 Specifikacija ciljeva kvalitete (Šatanová i sur., 2008)

\begin{tabular}{|c|c|c|c|c|c|c|c|}
\hline No. & \begin{tabular}{|l} 
Basic objectives \\
(Company level) \\
Osnovni ciljevi \\
(razina tvrtke)
\end{tabular} & No. & $\begin{array}{l}\text { Auxiliary objectives } \\
\text { (Dep. level) } \\
\text { Pomoćni ciljevi } \\
\text { (razina odjela) }\end{array}$ & $\begin{array}{l}\text { Dep. } \\
\text { Odjel }\end{array}$ & No. & $\begin{array}{l}\text { Auxiliary objectives } \\
\text { (Workplace level) } \\
\text { Pomoćni ciljevi (razina } \\
\text { radnog mjesta) }\end{array}$ & $\begin{array}{l}\text { Responsible } \\
\text { person } \\
\text { Odgovorna osoba }\end{array}$ \\
\hline 1. & $\begin{array}{l}\text { Identification of } \\
\text { business processes } \\
\text { Identifikacija } \\
\text { poslovnih procesa }\end{array}$ & 1.1 & $\begin{array}{l}\text { Map compilation } \\
\text { processes } \\
\text { Mapa skupine procesa }\end{array}$ & \multicolumn{4}{|c|}{$\begin{array}{l}\text { Department of quality management }(\mathrm{DQM}) \text { - Quality Manager } \\
\text { Odjel upravljanja kvalitetom (DQM) - Menadžer kvalitete }\end{array}$} \\
\hline \multirow[t]{4}{*}{2.} & \multirow[t]{4}{*}{$\begin{array}{l}\text { Claims Overview } \\
\text { Pregled zahtjeva }\end{array}$} & \multirow[t]{2}{*}{2.1} & \multirow[t]{2}{*}{$\begin{array}{l}\text { Monitoring the } \\
\text { number of claims } \\
\text { Praćenje brojnih } \\
\text { zahtjeva }\end{array}$} & DQM & & $\begin{array}{l}\text { Claims received from } \\
\text { customers } \\
\text { Zahtjevi zaprimljeni } \\
\text { od kupaca }\end{array}$ & $\begin{array}{l}\text { Quality Manager } \\
\text { Menadžer } \\
\text { kvalitete }\end{array}$ \\
\hline & & & & $\begin{array}{l}\text { Sales depart- } \\
\text { ment / Odjel } \\
\text { prodaje (SD) } \\
\end{array}$ & & $\begin{array}{l}\text { Claims addressed to } \\
\text { suppliers / Zahtjevi } \\
\text { upućeni dobavljaču }\end{array}$ & $\begin{array}{l}\text { Manager of SD } \\
\text { Menadžer prodaje }\end{array}$ \\
\hline & & \multirow[t]{2}{*}{2.2} & \multirow[t]{2}{*}{$\begin{array}{l}\text { Evaluation of the ratio } \\
\text { of claims to goods } \\
\text { Vrednovanje udjela } \\
\text { zahtjeva u dobru }\end{array}$} & DQM & & $\begin{array}{l}\text { Accepted claims for } \\
\text { invoiced goods } \\
\text { Prihvaćeni zahtjevi } \\
\text { naplaćenih dobara }\end{array}$ & $\begin{array}{l}\text { Quality Manager } \\
\text { Menadžer } \\
\text { kvalitete }\end{array}$ \\
\hline & & & & SD & & $\begin{array}{l}\text { Accepted claims for } \\
\text { goods ordered, with } \\
\text { respect to the material } \\
\text { Prihvaćeni zahtjevi } \\
\text { naručenih dobara, do } \\
\text { materijala }\end{array}$ & $\begin{array}{l}\text { Manager of SD } \\
\text { Menadžer prodaje }\end{array}$ \\
\hline \multirow[t]{5}{*}{3.} & \multirow[t]{5}{*}{$\begin{array}{l}\text { Production } \\
\text { efficiency } \\
\text { Efikasnost } \\
\text { proizvodnje }\end{array}$} & 3.1 & $\begin{array}{l}\text { Monitoring of control } \\
\text { points (check) } \\
\text { Praćenje kontrolnih } \\
\text { točaka }\end{array}$ & DQM & & $\begin{array}{l}\text { Final control - accor- } \\
\text { ding to the control } \\
\text { points / Završna } \\
\text { kontrola prema } \\
\text { kontrolnim točkama }\end{array}$ & $\begin{array}{l}\text { Quality Manager } \\
\text { Menadžer } \\
\text { kvalitete }\end{array}$ \\
\hline & & 3.2 & $\begin{array}{l}\text { Multiple errors } \\
\text { Višestruke pogreške }\end{array}$ & DQM & & $\begin{array}{l}\text { - for production } \\
\text { section } \\
\text { - za proizvodni dio }\end{array}$ & $\begin{array}{l}\text { Quality Manager } \\
\text { Menadžer } \\
\text { kvalitete }\end{array}$ \\
\hline & & 3.3 & $\begin{array}{l}\text { Nonconforming } \\
\text { products } \\
\text { Neprihvatljivi } \\
\text { proizvodi }\end{array}$ & $\begin{array}{l}\text { Manufacturing } \\
\text { department } \\
\text { Proizvodni odjel } \\
(M D)\end{array}$ & & $\begin{array}{l}\text { - for machines } \\
\text { - za strojeve }\end{array}$ & $\begin{array}{l}\text { Manager of MD } \\
\text { Menadžer } \\
\text { proizvodnog } \\
\text { odjela }\end{array}$ \\
\hline & & \multirow[t]{2}{*}{3.4} & \multirow[t]{2}{*}{$\begin{array}{l}\text { Productivity } \\
\text { Produktivnost }\end{array}$} & \multirow[t]{2}{*}{ MD } & & $\begin{array}{l}\text { Manufacture of } \\
\text { furniture } \\
\text { Proizvodnja } \\
\text { namještaja }\end{array}$ & $\begin{array}{l}\text { Manager of MD } \\
\text { Menadžer } \\
\text { proizvodnog } \\
\text { odjela }\end{array}$ \\
\hline & & & & & & $\begin{array}{l}\text { Production of } \\
\text { battenboard } \\
\text { Proizvodnja ploča }\end{array}$ & $\begin{array}{l}\text { Manager of MD } \\
\text { Menadžer } \\
\text { prozvodnog odjela }\end{array}$ \\
\hline \multirow[t]{2}{*}{4.} & \multirow{2}{*}{$\begin{array}{l}\text { Education and } \\
\text { training of } \\
\text { employees } \\
\text { Edukacija i trening } \\
\text { uposlenih }\end{array}$} & \multirow[t]{2}{*}{4.1} & \multirow[t]{2}{*}{$\begin{array}{l}\text { Training plan } \\
\text { Plan izobrazbe }\end{array}$} & \multirow{2}{*}{$\begin{array}{l}\text { Personal } \\
\text { departement / } \\
\text { Odjel kadrova } \\
(P D)\end{array}$} & & $\begin{array}{l}\text { Internal training } \\
\text { Interna izobrazba }\end{array}$ & $\begin{array}{l}\text { Manager of PD } \\
\text { Menadžer odjela } \\
\text { kadrova }\end{array}$ \\
\hline & & & & & & $\begin{array}{l}\text { External training } \\
\text { Vanjska izobrazba }\end{array}$ & $\begin{array}{l}\text { Manager of PD } \\
\text { Menadžer odjela } \\
\text { kadrova }\end{array}$ \\
\hline \multirow[t]{2}{*}{5.} & \multirow{2}{*}{$\begin{array}{l}\text { Quality evaluation } \\
\text { Vrednovanje } \\
\text { kvalitete }\end{array}$} & 5.1 & $\begin{array}{l}\text { Internal audits } \\
\text { Interni auditi }\end{array}$ & \multicolumn{4}{|c|}{ DQM - Quality Manager / Menadžer kvalitete } \\
\hline & & 5.2 & $\begin{array}{l}\text { External audits } \\
\text { Vanjski auditi }\end{array}$ & \multicolumn{4}{|c|}{ DQM - Quality Manager / Menadžer kvalitete } \\
\hline
\end{tabular}

Consequently, quarterly, and if necessary, half annual and annual summary reports about the quality costs would be compiled.

Effective control of economy in quality assurance will be implemented through a system of quality indicators. It provides the necessary information concerning the behavior of quality costs. It is a combina- tion of cost and performance parameters. The cost consists of the so-called ratios of different groups of quality costs.

For the purpose of quality control the most important elements are:

- an indicator of the proportion of internal losses to total operating costs 
...... Šatanová, Krajčírová: Application of Accounting and Reporting in a Cost-Oriented...

Table 2 Group quality costs (Šatanová et al., 2008)

Tablica 2 Skupine troškova kvalitete (Šatanová et al., 2008)

\begin{tabular}{|c|c|c|}
\hline $\begin{array}{l}\text { Code } \\
\text { / Kod }\end{array}$ & $\begin{array}{l}\text { Type of quality costs / Tip troškova } \\
\text { kvalitete }\end{array}$ & Content Items / Sadržaj \\
\hline N 1 & \multicolumn{2}{|l|}{ Prevention costs / Troškovi prevencije } \\
\hline N 1.1 & $\begin{array}{l}\text { Costs for the selection, approval and } \\
\text { evaluation of suppliers } \\
\text { Troškovi određivanja, odobrenja i } \\
\text { vrednovanja dobavljača }\end{array}$ & $\begin{array}{l}\text { Total expenditure for the specification of the quality of supply } \\
\text { Potpuni troškovi specifikacije kvalitete dobavljača }\end{array}$ \\
\hline N 1.2 & $\begin{array}{l}\text { Costs of internal audits } \\
\text { Troškovi internog audita }\end{array}$ & $\begin{array}{l}\text { Salaries and overhead costs for regular audits initiated by senior } \\
\text { management / Plaće i drugi troškovi za redoviti audit potaknut od } \\
\text { vrhovnog menadžmenta }\end{array}$ \\
\hline N 1.3 & $\begin{array}{l}\text { The cost of external audits } \\
\text { Troškovi vanjskog audita }\end{array}$ & $\begin{array}{l}\text { The amount invoiced by the audit point / Visina računa po točkama } \\
\text { audita }\end{array}$ \\
\hline N 1.4 & $\begin{array}{l}\text { Internal costs for training and education } \\
\text { of employees / Interni troškovi izobrazbe } \\
\text { i treninga uposlenika }\end{array}$ & Staff costs and overheads. / Troškovi osoblja i drugi troškovi \\
\hline N 1.5 & $\begin{array}{l}\text { External costs for training and education } \\
\text { of employees / Vanjski troškovi izobrazbe } \\
\text { i treninga uposlenika }\end{array}$ & $\begin{array}{l}\text { The amount invoiced by an educational organization (seminars, courses, } \\
\text { post-secondary studies, internships, etc.) / Iznos računa prema edukacij- } \\
\text { skoj razini (seminari, tečajevi, poststudiji, stažiranje i sl.) }\end{array}$ \\
\hline N 1.6 & $\begin{array}{l}\text { The cost of calibration services } \\
\text { Troškovi usluga uravnoteženja }\end{array}$ & $\begin{array}{l}\text { The amount invoiced by an external organization } \\
\text { Iznos računa vanjske organizacije }\end{array}$ \\
\hline $\mathrm{N} 2$ & \multicolumn{2}{|l|}{ Costs of evaluation / Troškovi vrednovanja } \\
\hline N 2.1 & $\begin{array}{l}\text { Cost of check-in control } \\
\text { Troškovi kontrole ulaza }\end{array}$ & $\begin{array}{l}\text { Material, labor and overhead costs of physical access control inputs, } \\
\text { auxiliary materials, chemical analysis and so on / Materijal, rad i drugi } \\
\text { troškovi fizičke kontrole ulaza, pomoćnih materijala, kemijske analize i sl. }\end{array}$ \\
\hline N 2.2 & \begin{tabular}{|l|} 
Costs of production control \\
Troškovi kontrole proizvodnje
\end{tabular} & $\begin{array}{l}\text { Material, labor and overhead costs of production control } \\
\text { Materijal, rad i drugi troškovi kontrole proizvodnje }\end{array}$ \\
\hline N 2.3 & $\begin{array}{l}\text { Costs of checkout control } \\
\text { Troškovi kontrole izlaza }\end{array}$ & $\begin{array}{l}\text { Material, labor and overhead costs of the final inspection } \\
\text { Materijal, rad i drugi troškovi završne kontrole }\end{array}$ \\
\hline N 2.4 & $\begin{array}{l}\text { Costs of internal laboratory tests } \\
\text { Troškovi internog testiranja u laborato- } \\
\text { riju }\end{array}$ & $\begin{array}{l}\text { Total operating costs of laboratory processes that ensure verification of } \\
\text { product compliance / Ukupni operativni troškovi laboratorijskog procesa } \\
\text { kako bi se osigurala potvrda kvalitete proizvoda }\end{array}$ \\
\hline $\mathrm{N} 2.5$ & $\begin{array}{l}\text { Costs for external laboratory tests } \\
\text { Troškovi vanjskog laboratorija }\end{array}$ & $\begin{array}{l}\text { The amount invoiced by an external organization / Ukupni iznos računa } \\
\text { vanjske organizacije }\end{array}$ \\
\hline N 2.6 & $\begin{array}{l}\text { Costs for the purchase and maintenance } \\
\text { of measuring devices / Troškovi nabave } i \\
\text { održavanja mjernih uređaja }\end{array}$ & $\begin{array}{l}\text { One-off investment and operating costs, including costs of repairs for all } \\
\text { types of measuring devices in the company / Jednokratna investicija } i \\
\text { operativni troškovi, uključujući troškove popravaka svih mjernih uređaja } \\
\text { u tvrtki }\end{array}$ \\
\hline N 3 & \multicolumn{2}{|l|}{ Internal losses / Interni troškovi } \\
\hline N 3.1 & $\begin{array}{l}\text { The cost of multiple errors } \\
\text { Troškovi višestrukihpo grešaka }\end{array}$ & $\begin{array}{l}\text { Materials, labor, overhead costs incurred due to improperly adjusted } \\
\text { equipment / Materijal, rad i drugi troškovi nastali zbog loše pripremljene } \\
\text { opreme }\end{array}$ \\
\hline N 3.2 & $\begin{array}{l}\text { The costs of additional work to repair } \\
\text { repairable nonconforming products } \\
\text { (rejects) / Troškovi dodatnog rada za } \\
\text { popravak nekvalitetnih proizvoda } \\
\text { (odbijeni) }\end{array}$ & $\begin{array}{l}\text { Cost of avoidable differences in semi-materials, materials and products } \\
\text { i.e. direct labor, direct material and the corresponding part of overheads } \\
\text { Troškovi mogućih izbjegavanja grešaka u poluproizvodima, materijalima } \\
\text { i proizvodima, tj. izravni rad, izravni materijal i pripadajući dijelovi kao } \\
\text { dodatni troškovi }\end{array}$ \\
\hline N 3.3 & $\begin{array}{l}\text { Irreparable loss of nonconforming } \\
\text { products (rejects) / Nepopravljivi gubici } \\
\text { zbog nekvalitetnih proizvoda }\end{array}$ & $\begin{array}{l}\text { The value of nonconforming materials, semi-materials and products, which } \\
\text { must be banned from further use / Vrijednost materijala, poluproizvoda } i \\
\text { nekvalitetnih proizvoda koji se moraju isključiti iz daljnje uporabe }\end{array}$ \\
\hline N 3.4 & $\begin{array}{l}\text { Unreclaimed losses from supply } \\
\text { differences / Neobračunani troškovi } \\
\text { razlika u specifikaciji dobavljača }\end{array}$ & $\begin{array}{l}\text { The value of unserviceable and unreclaimed nonalready purchased } \\
\text { material inputs, differences not caused by the manufacturer } \\
\text { Vrijednost nepopravljivoga i neobračunanoga nabavljenog materijala, } \\
\text { razlike koje nisu uzrokovane proizvodnjom }\end{array}$ \\
\hline $\mathrm{N} 4$ & \multicolumn{2}{|l|}{ External losses / Vanjski troškovi } \\
\hline N 4.1 & $\begin{array}{l}\text { The cost of nonconforming unrepairable } \\
\text { products (claims) / Troškovi nekvalitet- } \\
\text { nih nepopravljivih proizvoda (zahtjevi) }\end{array}$ & The value of external differences / Vrijednost vanjskih promjena \\
\hline N 4.2 & $\begin{array}{l}\text { Discount prices of products of substan- } \\
\text { dard quality / Snižena cijena zbog } \\
\text { nedovoljne razine kvalitete }\end{array}$ & $\begin{array}{l}\text { Loss difference between the normal selling price and the discounted price } \\
\text { Gubici zbog razlike između normalne prodajne cijene i snižene cijene }\end{array}$ \\
\hline $\mathrm{N} 4.3$ & $\begin{array}{l}\text { Transport costs caused by nonconfor- } \\
\text { ming products / Troškovi transporta } \\
\text { zbog nekvalitetnih proizvoda }\end{array}$ & $\begin{array}{l}\text { Transport, labor costs for handling external differences } \\
\text { Transport, troškovi rada zbog rukovanja nekvalitetnim proizvodom } u \\
\text { uporabi }\end{array}$ \\
\hline N 4.4 & $\begin{array}{l}\text { Travelling costs due to nonconforming } \\
\text { products / Troškovi puta zbog nekvalitet- } \\
\text { nih proizvoda }\end{array}$ & $\begin{array}{l}\text { Travelling costs for handling of external differences } \\
\text { Putni troškovi zbog rukovanja nekvalitetnim proizvodom u uporabi }\end{array}$ \\
\hline
\end{tabular}


Table 3 Quality cost report (Šatanová et al., 2008)

Tablica 3 Izvješće o troškovima kvalitete (Šatanová i sur., 2008)

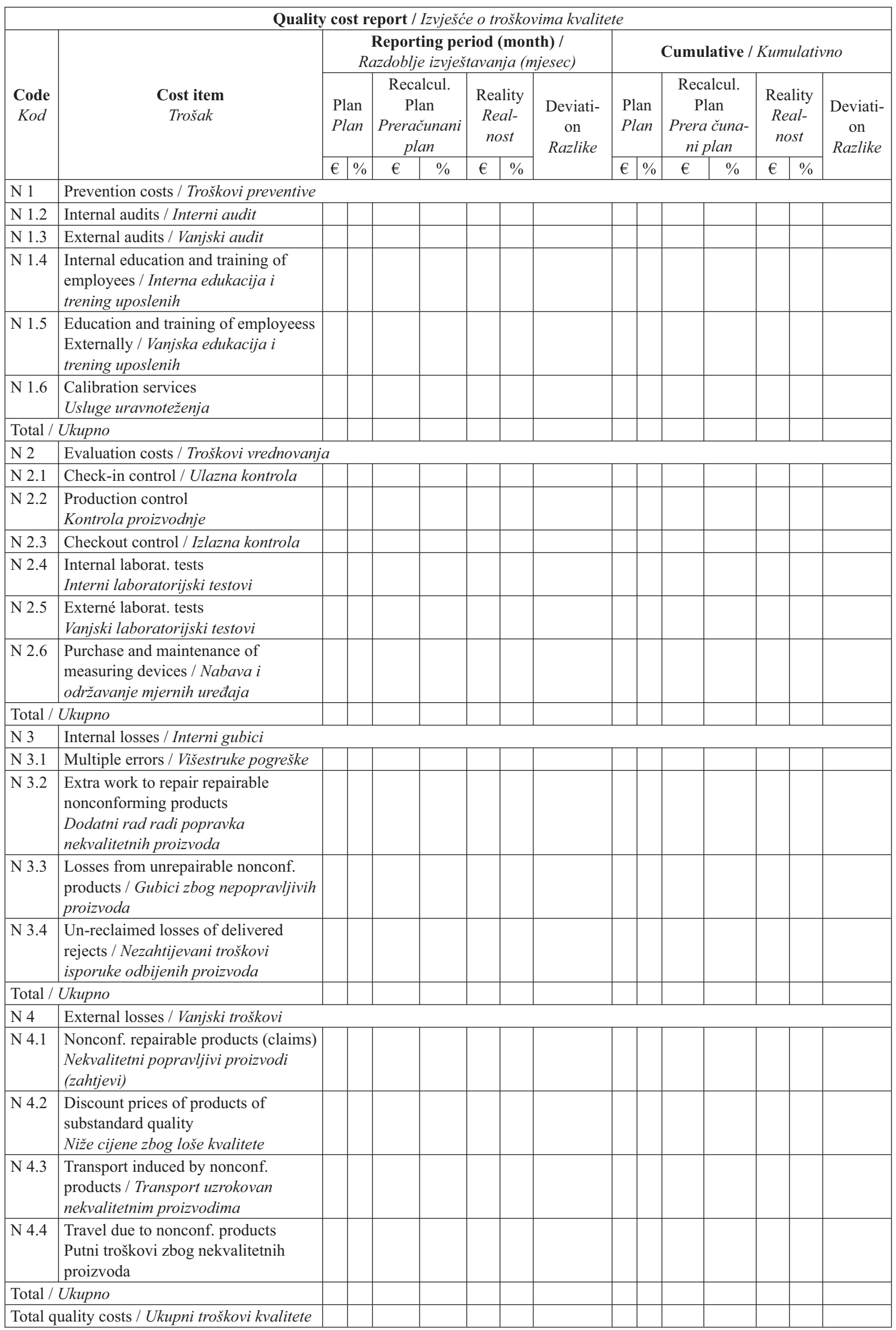


- an indicator of the proportion of external losses to total cost

- an indicator of the proportion of external losses to the turnover of company

- an indicator of the costs for the evaluation phase supply to the total purchase cost of materials

- an indicator of the proportion of operating costs for the evaluation of the total operating costs

- an indicator of total variable quality costs to the overall business costs and other

Based on the results obtained from the reports and parameter values, the benefits will reveal themselves arising from the applied methodology of the concept of quality control. The top management will then be informed about their performance in terms of quality and future measures necessary for ensuring and improving quality will be formulated.

The whole concept of the methodology of quality control can be summarized in the scheme below (see Fig. 2).

Verification is the final stage of the methodology of the concept of quality control (see Figure 2) and provides successful implementation of quality control in practice. In this way, the company has the possibility to detect and subsequently eliminate the shortfalls, thus leading to improvements in the quality of business processes and increasing overall efficiency.

\section{CONCLUSION}

\section{ZAKLJUČAK}

As companies seek to establish and implement a quality management system on their own terms, a system of monitoring and evaluating quality costs should be built in each of them. It should be noted, however, that ISO 9000 standards do not track quality costs, nor financial indicators or measurements. It is at the discretion of the company to decide whether and how to pay attention to this area. However, the fact remains that business sphere does not deal much with the given indicators and their monitoring, and that this analysis is significantly underestimated. Companies usually solve the problem of reducing costs only when dealing with the actual cost and with the related expenses. We have offered to companies an option to track their quality costs and subsequently to evaluate them. In this way, the possibility is provided of tracking the effects of quality costs. First, there are losses due to shortcomings in the field of quality assurance. However, there is also the opportunity to identify any significant effects on corporate performance, and the possibility of reducing the total costs of some performance indicators and quality management systems. It is possible to quantify any positive benefits either in production or in the user domain. Finally, it may create a basis for pricing the product or service that will take into account the quality taking into consideration producer and user benefits.

\section{REFERENCES}

\section{LITERATURA}

1. Macík, K., 1999: Kalkulace nákladu - základ podnikového controllingu, 1. vydání, Ostrava: Montax, , p. 241.

2. Potkány, M., 2005: System for establishing intradepartmental prices in Slovak wood processing industry. Drvna industrija, 56 (4): 177-178.

3. Potkány, M., 2009: The methodology of creation of basic budgets types in commercial enterprise at the furniture sales. In: Acta Facultatis xylologiae, vedecký časopis drevárskej fakulty, 51 (2): 105-119.

4. Šatanová, A.; Gejdoš, P.; Potkány, M., 2008: Manažérstvo kvality. Zvolen: TU Zvolen, p. 353.

5. Šatanová, A.; Rajnoha, R.; Drábek, J.; Volčko I.; Sedliačiková, M.; Merková, M., 2010: Kontroling. Zvolen: TU Zvolen, p. 116.

\section{Corresponding addresses:}

prof. Ing. ANNA ŠATANOVÁ, CSc.

Department of Business Economics

Faculty of Wood Science and Technology

Technical University in Zvolen

T. G. Masaryka 24

96053 Zvolen, SLOVAKIA

e-mail: satanova@vsld.tuzvo.sk 